\title{
The Current Situation and Reform Assumption of Sport Competitions in Colleges and Universities
}

\author{
Tan $\mathrm{Wu}$ \\ Public Basic Course Department \\ Wuhan Technology and Business University \\ Wuhan, P.R.China
}

\begin{abstract}
The implementation of Sports and Health Curriculum Standards sees the shortcomings in the traditional sport competition methods in colleges and universities because of too much emphasis on athletics. The thesis tries to give some suggestions on sport competition methods in colleges and universities, based on the analysis of the current situation of sport competitions in colleges and universities.
\end{abstract}

\section{Keywords-sport competition; the current situation; reform}

\section{INTRODUCTION}

The implementation of Sports and Health Curriculum Standards sees the shortcomings in the traditional sport competition methods in colleges and universities because of too much emphasis on athletics. Therefore, it is necessary to reform the traditional sport competition methods in colleges and universities and create an atmosphere of sport competition in which the students can be encouraged to give full play to their personalities and special skills and develop their non-intelligence factors. Meanwhile, the guidelines of Health First must be set up to make sure of the carrying-out of quality education and the fostering of students' lifelong physical culture awareness.

\section{The CURRENT SituAtion OF SPORT COMPETITIONS IN COLLEGES AND UNIVERSITIES}

\section{A. The Contents of Sport Competitions in Colleges and} Universities Cannot Satisfy the Health Need of Students

Under the guidance of new curriculum ideas, the sports work in colleges and universities must set up the guidelines of Health First and the goal of encouraging students to participate in sports lifelong. Therefore, sport competitions in colleges and universities must focus on the most students and interesting sport events. The present sport competitions in colleges and universities still focus on the competitive sport which needs more and more skills, but it turns out that those competitions are the low-level competitions of highlevel sports and the students' participating rates are low. In this way the goal of keeping fit is difficult to achieve.

\section{B. Sport Competitions in Colleges and Universities Tend to be Formal}

Before the yearly sports meet or ball games, students will be active in exercising for the honors of their classes. After those games, students are no longer to take part in the sport activities of colleges and universities. The extracurricular activities lose their charm in attracting the students to take part in and the students lose the effective time of physical exercise.

\section{The Form of Sport Competitions in Colleges and Universities Loses the Connection of Students' Physical Fitness Standards}

In the sport competitions of colleges and universities, students can only be "guests" because those athletic games are chosen. Moreover, many leaders and teachers do not attach much importance to the ideas of Students' Physical Fitness Standards. In the teaching reform, teachers still play the role of giver, while the students have to accept the knowledge imparted by the teachers. Some teachers overemphasize the interest and neglect the keeping-fit nature of physical education. Some teachers understand the new curriculum concepts as the reform of teaching forms, and therefore only focus on the change of teaching methods.

\section{There are Some Problems in Physical Talents Resources for the Sport Competitions in Colleges and Universities \\ Nowadays, there are some differences in the understanding of human resources in the physical education for different scholars. Some scholars think that the PE teachers in colleges and universities should be the educators of all-round development and then the director of sports. Some scholars think that the PE teachers in colleges and universities must have the advanced sports skills. Differen ideas lead to the difficult integration of PE teachers' resources in colleges and universities.}

\section{E. The Low Utilization Factors of Gyms in Colleges and Universities Influences the Enthusiasms of Students to do the Exercises}

With the merge of different colleges and universities, they attach much importance to the investment of $\mathrm{PE}$ facilities. The number of new gyms is on the increase, and 
they are of high levels. But actually the utilization factors of those gyms are very low. Generally the students do not have much access to the facilities in those gyms and they have to do the exercises on some poor courts. Thus, the students lose their interest and joy in doing the exercises, while those facilities become furnishings, which causes the waste of PE resources.

\section{THE REFORM ASSUMPTION OF SPORT COMPETITION METHODS IN COLLEGES AND UNIVERSITIES}

\section{A. PE Teachers in Colleges and Universities Should Adjust to the New Curriculum Concepts as Fast as Possible}

The physical education in colleges and universities must increase the students' physical quality in teaching activities integrating the fitness, sports and entertainment. The PE teaching systems based on the gymnastics, martial arts and athletics must be reformed and the new systems, committed to increasing the keeping-fit effects and cultivating students' lifelong physical abilities, must be constructed. Therefore, the PE teachers in colleges and universities must have creative ideas and higher PE cultural quality. And they must keep studying some knowledge about PE teaching.

\section{B. The Sport Competitions in Colleges and Universities should be Connected with National Fitness Program}

National Fitness Program is the guiding outline of the comprehensiveness of social physical education in our country. To realize the organic combination of PE in colleges and universities and social PE, the sport competitions in colleges and universities should get through the limit of single athletic games and integrate some athletic sport events, which are appropriate for college students to keep fit, and popular sport events, which involve the fun, joy, fitness and national character. Thus, the new system of sport competition contents will be gradually formed, with the special characteristics of colleges and universities.

\section{The Sport Competitions in Colleges and Universities should Get Connected to the PE Tests}

The contents and forms of PE tests can promote the full development of students' sport abilities and body diathesis. For example, the long jump can be one of the sport competition events and one of the test contents. Through the sport competitions, every student can experience the joy of doing the sports and they will be more active in doing the sports.

\section{The Sport Competitions in Colleges and Universities should Adopt Different Evaluation Methods in PE Teaching}

The old evaluation on PE teaching overemphasizes the quantitative assessment and final assessment. The sport competitions in colleges and universities should be combined with the new curriculum standards and focus on the quantitative and qualitative evaluations. At the same time, the relevant and absolute evaluations are also valued. The old $\mathrm{PE}$ teaching evaluating forms involve the outer evaluation of the students only made by the teachers, which neglect the positiveness of students to participate in the evaluation. New curriculum standards advocate the evaluation of the students made by teachers, students themselves and their classmates, when the students are assessed in their performances in PE classes. Thus the functions of students themselves and the teams will be given full play to in the evaluating process to realize the diversity of evaluation subjects. Therefore, in the sport competitions, the diversified evaluating methods should be adopted to attract more students to participate into the sport competitions.

\section{E. The Sport Competitions in Colleges and Universities should Include the Students' Sports Cultural Quality}

The sport competitions in colleges and universities allow the organizers to develop different activities of diversity, interest and fun. The interest of students in the sports can be aroused through the contest of PE knowledge, the TV debate on PE, the PE speech contest, the exhibitions of pictures and photographs of sports, etc. In this way, the PE awareness can be reinforced and the concepts of lifelong sports will be set up.

\section{F. The Sport Competitions in Colleges and Universities should be Faced to all the Students and Make Sure of the Competition Time}

The sport competitions in colleges and universities should attract all the students and make the sport activities popular with many people. Nowadays, college students have the pressure of finding jobs and the heavy burden of passing the different exams. To liberate the students from those pressures and burdens, extracurricular activities should be organized to arouse students' interest in the sports and enhance the comprehensive quality of them.

\section{CONCLUSION}

The system of the sport competitions in colleges and universities is necessary to be innovative under the new concepts. The innovation of the sport competitions in colleges and universities is first of all the innovation of the concepts, then the teaching thoughts and the teaching practice. Through different innovations, the appearance of the sport competitions in colleges and universities can be changed and the new concepts of new curriculum standards can be realized. Thus, all people can attain the goal of keeping fit.

\section{REFERENCES}

[1] The Ministry of Education of PRC, the State General Administration of Sports. The explanation on Student Physical Fitness Stand(pilot scheme)[M]. Beijing: People's Educational Publishing House, 2002.

[2] Yao Ping. Problems and Reform Ideas in the Sport Competitions in Colleges and Universities[J]. Education of Modern Primary and Middle School, 2004,(6): 33-34.

[3] Yu Xuehao. The Basic Thoughts about the PE Teaching Reform under the New Curriculum Standards[J]. Journal of Beijing University of Physical Education, 2004, 27(5): 668-670. 
[4] Li Tianbai, Jiang Rong. The Correspondent Problems Research in the Development of PE in Chinese and Foreign Colleges and Universities[J]. Education and Vocation, 2004, (27): 61-63. 